$$
\angle O M=8968 / 0 \ldots 3
$$

Reci. :y OSTI

AUG 071989

GA-A19702

\title{
PERSPECTIVES OF MODULAR HIGH TEMPERATURE GAS-COOLED REACTOR (MHTGR) ON EFFLUENT MANAGEMENT AND SITING
}

by

T. DUNN, J. CARDITO, and J. CUNLIFFE

DO NOT MICROFILM

COVER

JULY 1989

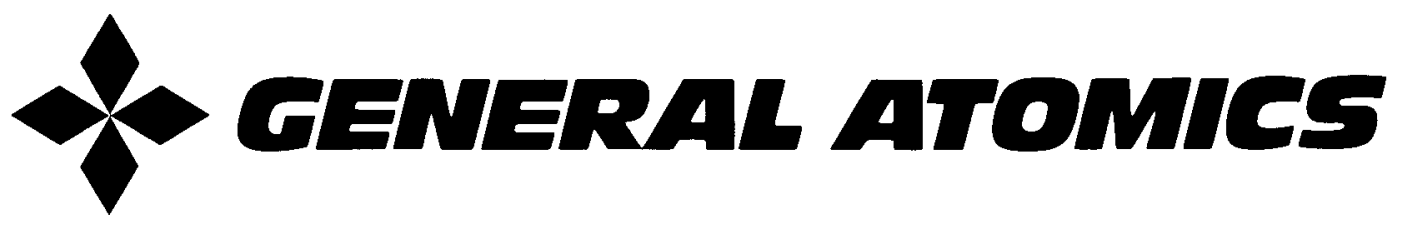

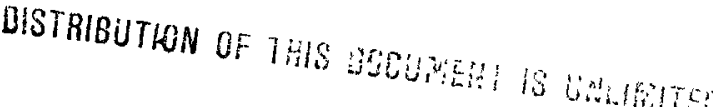




\title{
PERSPECTIVES OF MODULAR HIGH TEMPERATURE GAS-COOLED REACTOR (MHTGR) ON EFFLUENT MANAGEMENT AND SITING
}

\author{
by \\ T. DUNN, J. CARDITO*, and J. CUNLIFFE**
}

This is a preprint of a paper to be presented at the Post-SMiRT Conference Seminar on "Small and Medium-Sized Reactors: You and Your Environment," August 21-23, 1989, San Diego, California.

"Stone \& Webster Engineering Corporation

**Bechtel National Inc.

\author{
Work Supported by \\ Department of Energy \\ Contract No. DE-AC03-89SF17885
}

GENERAL ATOMICS PROJECT 7600

JULY 1989

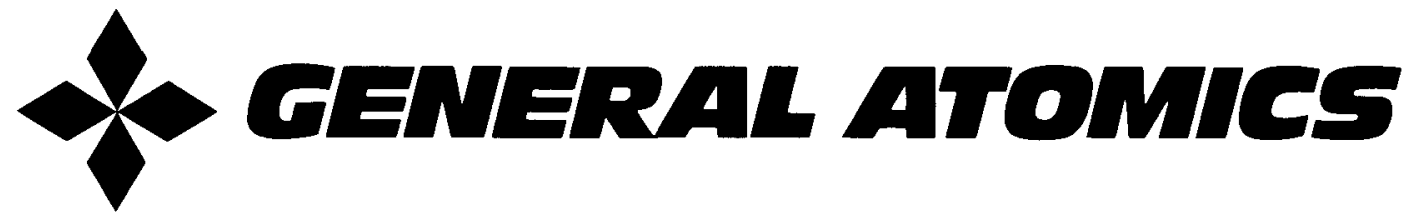




\section{DISCLAIMER}

This report was prepared as an account of work sponsored by an agency of the United States Government. Neither the United States Government nor any agency Thereof, nor any of their employees, makes any warranty, express or implied, or assumes any legal liability or responsibility for the accuracy, completeness, or usefulness of any information, apparatus, product, or process disclosed, or represents that its use would not infringe privately owned rights. Reference herein to any specific commercial product, process, or service by trade name, trademark, manufacturer, or otherwise does not necessarily constitute or imply its endorsement, recommendation, or favoring by the United States Government or any agency thereof. The views and opinions of authors expressed herein do not necessarily state or reflect those of the United States Government or any agency thereof. 


\section{DISCLAIMER}

Portions of this document may be illegible in electronic image products. Images are produced from the best available original document. 
PERSPECTIVES OF MODULAR HIGH TEMPERATURE GAS-COOLED REACTOR (MHTGR) ON EFFLUENT MANAGEMENT AND SITING

T. Dunn ${ }^{1}$, J. Cardito 2 , J. Cunliffe $e^{3}$

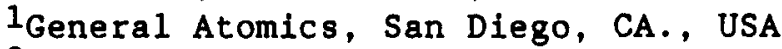

2 Stone \& Webster Engineering Corporation, Boston, MA., USA

${ }^{3}$ Bechtel National, Inc., San Francisco, CA., USA

\section{ABSTRACT}

The MHTGR is an advanced reactor concept being developed under a cooperative program involving the U.S. Government, the utilities and the nuclear industry. The programs objective is the development of an environmentally safe, reliable, and economic nuclear power option for the USA and other nations of the world. HTGR design features, such as the ceramic fuel, helium coolant, and graphite moderator, are incorporated into the MHTGR reference plant design which incorporates four $350 \mathrm{MW}(t)$ reactor modules. This papers objective is to describe those plant features, which minimize the environmental impact of MHTGR operation through efficient energy production, management of normal plant non-radioactive/radioactive effluents, and inherent characteristics and passive safety features which ensure benign plant site suitability source terms.

Key Words: Gas cooled reactor, effluent management, siting

\section{DESIGN DESCRIPTION}

The reference MHTGR plant design includes four $350 \mathrm{MW}(t)$ reactor modules coupled to two steam turbine generators that produce a net electrical output of $540 \mathrm{MW}(\mathrm{e})$. The design draws upon proven technology in operating nuclear and fossil-fired plants. Table 2-1 summarizes key design parameters for the MHTGR. The modular reactor components are contained within a steel vessel system made up of a reactor vessel, a steam generator vessel and a connecting crossduct vessel. Operating and decay heat loads from the reactor are normally removed through the steam generator or shutdown cooling heat exchanger utilizing helium gas circulators. The reactor vessel is uninsulated to provide for decay heat removal under loss-of-forced circulation conditions. In such events, heat is transported to the passive reactor cavity cooling system (RCCS), which circulates outside air by natural circulation within enclosed panels surrounding the reactor vessel. Each reactor module is housed in adjacent, but separate, reinforced concrete silos located below grade and enclosed by a common maintenance hall. Auxiliary structures that house common systems for fuel handling, helium processing and other essential services, complete the Nuclear Island portion of the plant. Remaining plant facilities are similar to those found in a modern fossil-fired plant.

\subsection{NORMAL OPERATION RELEASES}

Criteria utilized in developing the MHTGR provide for the protection of the public and the environment. For routine operation, this includes 
meeting regulations specifying limits on the release of liquid, gaseous, and solid releases of radioactive materials to the environment as embodied in 10CFR20, 10CFR50, 10CFR61, and 40CFR190. (Refs. 2,3,4 and 5).

Routine plant operation results in small quantities of radionuclides being released into the environment. Fort. St. Vrain (FSV) operating experience has proven that HTGR gaseous, liquid, and solid wastes are typically over an order of magnitude lower than the average for the US nuclear power industry (Ref. 6). Based upon extensive nuclear plant operating experience, MHTGR waste treatment systems will reduce liquid and gaseous radioactive materials to a small fraction of regulatory limits. The following sections discuss the MHTGR waste treatment systems.

\subsection{LIQUID EFFLUENTS}

During routine operation, radioactive liquid wastes from the MHTGR are segregated into two categories. The bulk of the waste, which is low in electrical conductivity (less than $50 \mathrm{mho} / \mathrm{cm}$ ) and varied in radioactivity level, is collected in a receiver tank. On a batch basis, low conductivity liquid waste is processed through a filter/demineralizer. Although higher decontamination levels are achieved with evaporators, LWR experience indicates that demineralizers are easier to operate and are subject to less operational upset. Treated liquid from the demineralizer is collected in a test tank for monitoring prior to discharge. The high conductivity waste stream is collected in a separate receiver tank and consists of highly tritiated waste and wastes from decontaminating equipment.

The expected annual radioactive liquid effluent releases given in Table $3-1$ are estimated to result in radionuclide concentrations five to eight orders of magnitude lower (depending upon the radionuclide) than the maximum permissible concentration limits of 10CFR20. This estimation assumes a 20 to 1 dilution of the liquid effluent by a cooling tower blowdown flow prior to discharge to the environment. Although utilization of a cooling tower results in lower effluent flows and higher effluent concentrations than use of a cooling reservoir, the reference MHTGR design includes cooling towers for siting flexibility (since a large body of water is not required for an MHTGR site). Lower radiation levels in MHTGR releases permit equipment design selections which improve plant availability (such as the increased reliability associated with demineralizers).

\subsection{GASEOUS EFFLUENTS}

During routine operation, sources of radioactive gaseous releases from the MHTGR include: reactor building ventilation, helium purification, gaseous radioactive waste system, and neutron activation of air circulating through the Reactor Cavity Cooling System (RCCS). 
Utilizing redundant high efficiency particulate/charcoal filtration assemblies and redundant waste gas exhaust blowers, the Gaseous Waste system filters, monitors, and subsequently releases nonradioactive or low-level activity gases to the environment as an elevated release. In the event of a high activity alarm, the flow stream is diverted to the waste gas vacuum tank for treatment until the high-activity source is isolated. Radioactive gases or gases potentially above a preset activity limit are accumulated within the waste gas vacuum tank, compressed by diaphragm compressors. Surge tanks retain these gases for 30 days to allow for radioactive decay. Then, this gas is released to the environment again as an elevated release. Helium and noble gases from the waste gas surge tanks are not recycled as the cost saving does not appear to justify the additional capital costs for equipment, controls, piping, valves, and building space required to recover the helium.

The maximum expected radionuclide concentration from gaseous effluent releases for all MHTGR sources are a small fraction of 10CFR20 limits. In the USA, concomitant doses associated with gaseous effluent releases must also meet 10CFR50, App. I limits. Using conservative site meteorological parameters, it has been shown that the concomitant doses for MHTGR releases are over an order of magnitude below 10CFR50 App I limits. Table 3-1 provides the annual releases of dominant dose-contributing gaseous radionuclides generated by the MHTGR (Ref. 1).

\subsection{SOLID WASTE}

Solid radioactive waste materials from the MHTGR include solidified wet wastes, spent resin from liquid waste process demineralizers, spent filter cartridges, high-temperature filter units, low-level compressible wastes, High Efficiency Particulate Absorbers (HEPA) and charcoal filtration units and miscellaneous solid materials which become radioactive during plant operation or maintenance. Wet wastes, such as high conductivity decontamination solutions, highly tritiated liquids and spent resins, and noncompactible wastes, such as contaminated tools, incore devices or small components that have become contaminated, are stabilized utilizing cement solidification to meet stabilization requirements of 10CFR61 for disposal of radioactive wastes: A compactor, which includes a ventilated shroud for dust control, provides volume reductions of 50 to $85 \%$ for dry compressible wastes such as rags, paper, or clothing. Large noncompactible waste items are cut utilizing an industrial robot.

Spent graphite reflector blocks from the reactor core are also classified as 
low level solid radioactive waste. The used graphite blocks are placed in drums and stored in a shielded area prior to shipping. To reduce radiation exposure during drum handling, the drums will be filled with grout if necessary.

The volume of solid radioactive waste expected to be generated from the MHTGR is estimated as $90 \mathrm{~m}^{3} / \mathrm{yr}$. This waste volume is primarily comprised of used reflector blocks, but includes other material as discussed above. The quantity of radioactivity contained in the solid radioactive waste is estimated at $470 \mathrm{Ci} / \mathrm{yr}$. The great majority of this activity is from decontamination operations and contained in solidified chemical solutions utilized in decontamination operations. However, FSV only generated $134 \mathrm{~m}^{3}$ of low level solid waste containing an estimated $437 \mathrm{CI}$ during over a 14 year period. As the program proceeds, additional work will be performed to better define MTHGR solid waste estimates.

\subsection{SPENT FUEL}

Although beneficial for safety and investment protection reasons, certain MHTGR design features (such as low power densities and a relatively short fuel cycle length) increase the rate at which spent fuel is generated. However, the level of activity release from spent fuel elements is low since the major barriers to radionuclide release from an HTGR fuel element, the fuel kernel, its particle coatings and the fuel element graphite, are present when it is removed from the core.

The MHTGR fuel cycle utilizes a three-year fuel residence time, replacing approximately one-half of the vertical fuel columns every 20 months. Six spent fuel storage pools provide interim fuel storage. The spent fuel is stored for at least 100 days to allow the decay heat generation rate to decrease sufficiently to permit shipment to permanent storage offsite (capacity is provided in the spent fuel storage pools to allow on-site storage for up to 1 year before shipment or other disposition).

The expected MHTGR spent fuel volume is $130 \mathrm{~m}^{3} / \mathrm{GW}(e)-\mathrm{yr}$. With fuel rod push out this reduces to $30 \mathrm{~m}^{3} / \mathrm{GW}(e)-\mathrm{yr}$, comparable to LWR spent fuel volumes. An important factor in evaluating the benefits of this volume reduction approach is the classification of waste level for the residual graphite blocks with the fuel rods removed. Preliminary results confirm that the empty fuel blocks could be classified as low level wastes (Ref. 7). Successful hot and cold cell demonstrations of HTGR fuel processing techniques confirm that additional methods may be utilized to further reduce HTGR fuel volumes (Ref. 8). Furthermore, measurements of a FSV fuel-element graphite sample indicate that, after rod pushout, the element's graphite retains radionuclides such that radioactivity levels meet 10CFR61 limits for low level waste (Ref. 4).

The provisions of the Civilian Radioactive Waste Management Program (Ref. 9) designate the responsibility for shipment and disposal of spent fuel to the DOE. Although preliminary analyses indicate that fully exposed fuel elements may be shipped offsite after 100 days of storage, additional onsite storage facilities may be required due to delays in implementing the Civilian Radioactive Waste Management Program. If spent fuel must be placed in 
expanded onsite storage facilities, the requirements for decay heat removal and gamma shielding are significantly reduced from the requirements for the fuel storage pools which must accept spent fuel within a few hours after reactor shutdown. For example, the nominal heat load from a spent fuel element one year after shutdown is about $5 \%$ of the heat rate for a nominal element 30 hrs after shutdown (Ref. 7).

\subsection{NONRADIOACTIVE EFFLUENTS}

As with any other nuclear power plant, the MHTGR produces effluents not immediately related to its heat source and, therefore, nonradioactive in nature. Water usage associated with meeting power cycle heat dissipation requirements are also important in assessing the environmental impact associated with power plant operation. Furthermore, nonradioactive effluents may contain industrial toxins and chemicals whose release must be closely controlled. Preliminary results indicate that the characteristics of the MHTGR are such that these nonradioactive effluents will be lower than those produced by existing LWR plants and some fossil-fired facilities.

\subsection{HEAT REJECTION IN COOLING WATER}

Waste heat from MHTGR plant components and internal closed cooling water is removed by several systems. The Service Water system removes heat from the Nuclear Island process systems using two $100 \%$ capacity service water pumps. The Circulating Water system removes waste heat from the condenser and the turbine building component cooling water heat exchangers. In normal operation, circulating water is pumped from the cooling tower basin through the condenser and heat exchangers and back to the cooling tower. The condenser heat load is rejected to the atmosphere by means of mechanical draft wet cooling towers.

The overall efficiency of the MHTGR is $38.4 \%$. Overall efficiencies for operating HTGR plants, such as the FSV (39\%) and THTR (41\%) plants, demonstrate the ability of HTGRs to achieve higher efficiencies than existing nuclear and fossil-fired plants. Power plants with higher overall efficiencies reject less waste heat to the environment. For example, a typical fossil plant with an efficiency of $35 \%$ will reject $16 z$ more heat than the MHTGR. The higher plant efficiency for the MHTGR is beneficial for both economic and environmental reasons.

\subsection{INDUSTRIAL TOXINS AND CHEMICALS}

In the operation of steam electric power plants, chemicals and biocides are added to water systems and eventually discharged to the environment. Additions of chemicals or biocides are made to control corrosion or biofouling. Similarities in operating characteristics of MHTGR and LWR water systems suggest that no significant differences exist in the chemical concentration in their effluent streams. Hence, the difference in the quantities of chemicals and biocides released would be primarily due to the difference in the magnitude of the effluent flow rate. Since the MHTGR dissipates less heat than conventional power plants, the MHTGR requires less cooling water flow for equivalent electric production at the same site.

The nonradioactive effluents produced from components within the reactor 
modules and related auxiliary structures are limited to collected equipment and floor drainage and equipment cleaning wastes generated during start-up and following equipment maintenance. Only a small amount of the drainage must be treated or disposed of as oily waste.

Other significant effluents produced by existing LWR nuclear plants are reduced or completely eliminated in the MHTGR design as summarized below:

- The once-through MHTGR steam generator eliminates the significant steam generator blowdown and wet layup wastes produced by PWRs (Ref. 10);

- Chemical additives in effluents associated with active safety-related heat removal or cooling water systems are eliminated;

- Elimination of a need for an active safety related heat sink facility precludes associated effluent releases;

- Combustion emissions associated with tests to satisfy safety-related requirements for emergency electrical generating capabilities are eliminated.

Similarly, many of the effluents that would be produced by a coal-fired plant of the same capacity of the MHTGR are also reduced or completely eliminated with the MHTGR. Coal-fired power plants release significant levels of combustion products to the atmosphere. The quantities released from a specific plant are dependent on the type of coal, installed equipment, and local regulations. However, to comply with the New Source Performance Standards of 40CFR60 (Ref. 11), a coal plant of similar size to the MHTGR could release 10500-16800 tons of $\mathrm{NO}_{x}$, 630 tons of particulates and 12600-25200 tons of $\mathrm{SO}_{2}$ annually.

Beyond this, coal-fired plants produce significant quantities of liquid waste effluent from such processes as flue gas desulfurization, fly ash flushing, and coal yard dust suppression. While some modern coal-fired plants, such as Utah's Warner Valley Plant ( 500 MWe net, twin turbine), maximize water recycle and direct non-re-usable water to evaporation ponds so that there is zero discharge of liquid waste, they must dedicate considerable land area to these liquid disposal facilities (e.g. approximately 485 hectares $(1,200$ acres) in the case of Warner Valley) (Ref. 12).

\subsection{MHTGR SITING SOURCE TERM RELEASES}

10CFR100 (Ref. 13) provides site suitability evaluation criteria for stationary power reactors. One of the important parameters evaluated for a proposed site is the identification of potential accidental radionuclide releases from the reactor plant. In this regard, the generic guidance on source terms in 10CFR 100 is that the radionuclide release should be postulated from consideration of a spectrum of possible accident events that would result in potential hazards "not exceeded by those from any accident considered credible".

The MHTGR program has identified a spectrum of possible accidental release scenarios that form a basis for determining the MHTGR site suitability source terms. This basis, consistent with 10CFR100 guidelines, includes an evaluation of a spectrum of accidents to determine a set of conservative source terms. 
This spectrum of accidents is represented by a set of Licensing Basis Events (LBEs). These MHTGR LBEs are:

1) logically chosen, following a structured method to consider a wide spectrum of possible events. Events are initially selected by engineering judgement and are reconfirmed by a safety risk assessment (Level 3 per NRC NUREG/CR 2300, Ref. 15),

2) assured of being encompassing through the inclusion of a mix of accident phenomena that incorporate varying release rates, release mixes, fallure states of barriers, chemical attack conditions and release from multiple reactor modules,

3) bounding, by considering all conceivably credible accidents, including those not expected to occur in the lifetime of several hundred MHTGR plants (down to a mean frequency of $5 \times 10^{-7} /$ plant year),

4) conservative, by including statistical accounting of uncertainties in calculations,

5) based upon a method that provides enhanced safety margins, consistent with NRC's Advanced Reactor Policy.

Not all LBEs result in a release of radionuclides from the plant. However, those that do involve release from the plant are identified in Table 4-1. The frequency range and the applicable criteria against which compliance is demonstrated are also identified in Table 4-1. The MHTGR approach evaluates site suitability with respect to the regulatory criteria applicable not only for off-normal events, but also for normal operation (as discussed in section 3.0 ) and emergency planning.

An assessment of all the MHTGR LBEs and the resultant radionuclide source terms are given in the Preliminary Safety Information Document (Ref. 14) and the Emergency Planning Basis Report (Ref. 16). A summary of the source terms for some key radionuclides are given in Table 4-2 for the LBEs that result in a radionuclide release from the plant. The source term shown is for a single, specific, and independent event, and therefore, the source terms are not additive. The MHTGR plant design is such that the releases are at ground level.

The source terms shown in Table 4-2 are extremely small. Thus, they result in offsite doses that are well below the threshold values of the Protective Action Guides (PAG) at which offsite public sheltering or evacuation should be initiated.

\subsection{CONCLUSIONS}

Building upon HTGR operating experience, an MHTGR plant has been designed to provide highly reliable, economic, and safe nuclear power. As demonstrated by results within this paper, MHTGR characteristics, such as low radioactive effluents and high thermal efficiency, combine to provide a very high degree of 


\begin{tabular}{|c|c|c|c|}
\hline \multicolumn{4}{|c|}{$\begin{array}{l}\text { Table } 4-1 \\
\text { Release Scenarios }\end{array}$} \\
\hline Release Scenarios & $\frac{\text { Scenario }}{\text { Designation }}{ }^{*}$ & $\frac{\text { Frequency }}{\text { IPlant Yr }}$ & Criteria \\
\hline Normal Releases & $\cdots-$ & $\begin{array}{l}\text { Normal Plant } \\
\text { Operation }\end{array}$ & 10CFR50 \\
\hline $\begin{array}{l}\text { Small Primary Coolant Leak } \\
\text { with Forced Core Cooling }\end{array}$ & AOO-5 & $>.025$ & $\begin{array}{l}\text { 1OCFR50 } \\
\text { APP I }\end{array}$ \\
\hline $\begin{array}{l}\text { Moisture Inleakage Without } \\
\text { Forced core Cooling }\end{array}$ & DBE -7 & .025 to $10^{-4}$ & 10CFR100 \\
\hline $\begin{array}{l}\text { Primary Coolant Leak } \\
\text { With Forced Core Cooling }\end{array}$ & $D B E-10$ & .025 to $10^{-4}$ & 10CFR100 \\
\hline $\begin{array}{l}\text { Primary Coolant Leak } \\
\text { without Forced Core Cooling }\end{array}$ & DBE-11 & .025 to $10^{-4}$ & 10CFR100 \\
\hline $\begin{array}{l}\text { Moisture Inleakage With } \\
\text { Delayed Steam Generator } \\
\text { Isolation and Without } \\
\text { Forced Core Cooling }\end{array}$ & EPBE-1 & $10^{-4}$ to $5 \times 10^{-7}$ & Lower PAG \\
\hline $\begin{array}{l}\text { Moisture Inleakage with } \\
\text { Delayed Steam Generator } \\
\text { Isolation and with } \\
\text { Forced Core Cooling }\end{array}$ & $E P B E-2$ & $10^{-4}$ to $5 \times 10^{-7}$ & Lower PAG \\
\hline $\begin{array}{l}\text { Primary Coolant Leak } \\
\text { with Forced Core Cooling } \\
\text { * AOO= Anticipated Operati } \\
\text { DBE }=\text { Design Basis Event } \\
\text { EPBE }=\text { Emergency Planning }\end{array}$ & $\begin{array}{l}\text { nal Occurrence } \\
\text { asis Event }\end{array}$ & $10^{-4}$ to $5 \times 10^{-7}$ & Lower PAG \\
\hline
\end{tabular}

environmental compatibility. In addition, these MHTGR characteristics allow equipment design selections which further enhance the plant's availability and increase siting flexibility.

Site suitability source terms have been derived consistent with regulatory requirements using a logical approach to bound all credible accidents. Because of the MHTGR's inherent characteristics and passive safety features, the source terms are benign, requiring no sheltering or evacuation of the public beyond the site boundary.

\section{ACKNOWLEGEMENT}

The authors would like to thank the U.S. Department of Energy for approval to publish this work, which was supported by the San Francisco Operations Office, Contract DE-AC03-89SF17885. 


\begin{tabular}{|c|c|c|c|c|c|c|}
\hline \multirow[b]{3}{*}{ Event } & \multicolumn{5}{|c|}{$\begin{array}{c}\text { Table } 4-2 \\
\text { SOURCE TERMS OF KEY NUCLIDES FOR LICENSING BASIS EVENTS }\end{array}$} & \multirow[b]{3}{*}{ Cs-137 } \\
\hline & \multirow{2}{*}{$\begin{array}{l}\text { Number of } \\
\text { Modules }\end{array}$} & \multirow{2}{*}{$\begin{array}{l}\text { Release } \\
\text { Duration } \\
\text { (hours) }\end{array}$} & \multicolumn{3}{|c|}{ Cumulative Fractional Release to the Environment ${ }^{*}$} & \\
\hline & & & $\mathrm{Kr}-88$ & Sr-90 & $\mathrm{I}-131$ & \\
\hline $\mathrm{A} 00-5$ & 1 & $0-1.25$ & $1.4 \times 10^{-7}$ & $1.1 \times 10^{-11}$ & $3.1 \times 10^{-10}$ & $1.5 \times 10^{-10}$ \\
\hline DBE-7 & 1 & $0-0.02$ & $7.5 \times 10^{-9}$ & $5.4 \times 10^{-9}$ & $3.1 \times 10^{-8}$ & $9.2 \times 10^{-7}$ \\
\hline DBE-10 & 1 & $0-1$ & $2.2 \times 10^{-7}$ & $1.1 \times 10^{-10}$ & $8.0 \times 10^{-10}$ & $3.4 \times 10^{-9}$ \\
\hline \multirow[t]{2}{*}{ DBE-11 } & 1 & $0-8$ & $2.4 \times 10^{-8}$ & $2.2 \times 10^{-12}$ & $4.5 \times 10^{-9}$ & $2.6 \times 10^{-11}$ \\
\hline & & $0-100$ & $3.3 \times 10^{-8}$ & $9.9 \times 10^{-12}$ & $2.8 \times 10^{-7}$ & $4.4 \times 10^{-11}$ \\
\hline \multirow[t]{2}{*}{ EPBE-1 } & 1 & $0-8$ & $9.7 \times 10^{-7}$ & $4 \times 10^{-8}$ & $3.6 \times 10^{-7}$ & $3.6 \times 10^{-6}$ \\
\hline & & $0-100$ & $9.9 \times 10^{-7}$ & $4 \times 10^{-8}$ & $4.9 \times 10^{-7}$ & $3.8 \times 10^{-6}$ \\
\hline EPBE-2 & 1 & $0-8$ & $2.6 \times 10^{-7}$ & $1.1 \times 10^{-7}$ & $3.6 \times 10^{-7}$ & $1.9 \times 10^{-5}$ \\
\hline \multirow[t]{2}{*}{ EPBE-3 } & 4 & $0-8$ & $8.2 \times 10^{-8}$ & $8.2 \times 10^{-12}$ & $1.5 \times 10^{-9}$ & $1.0 \times 10^{-10}$ \\
\hline & & $0-100$ & $1.6 \times 10^{-7}$ & $3.8 \times 10^{-11}$ & $9.5 \times 10^{-7}$ & $1.7 \times 10^{-10}$ \\
\hline
\end{tabular}

* Fractions of Initial Radionuclide Inventory of $9.9 \times 10^{6} \mathrm{Ci}$ of $\mathrm{Kr}-88,7.4 \times 10^{5} \mathrm{Ci}$ of $\mathrm{Sr}-90,9.3 \times 10^{6} \mathrm{Ci}$ of I-131, and $8.6 \times 10^{5} \mathrm{Ci}$ of $\mathrm{Cs}-137$ 


\subsection{REFERENCES}

1. "Conceptual Design Summary Report Modular High-Temperature Gas Cooled Reactor Plant," DOE-HTGR-87092, September 1987.

2. Code of Federal Regulations, Title 10, Part 20, "Standards for Protection Against Radiation," Revised February 12, 1988.

3. Code of Federal Regulations, Title 10, Part 50, App. I, "Numerical Guides and Design Objectives and Limiting Conditions for Operation to Meet the Criterion As Low As Reasonably Achievable for Radioactive Material in Light Water Reactor Effluents," Revised November 6, 1986.

4. Code of Federal Regulations, Title 10, Part 61, "Licensing Requirements for Land Disposal of Radioactive Waste," Revised February 1, 1988

5. Code of Federal Regulations, Title 190, Part 190, "Environmental Radiation Protection Standards For Nuclear Power Operations, "January 13, 1977.

6. Brey, H.L., "Fort St. Vrain Performance," IAEA Technical Committee Meeting on Gas-Cooled Reactors and Their Applications, "Juelich, FRG, October 20-23, 1986.

7. Baxter, B.J., Cohen, M.E., and Lane, R.K., "The Economics of Spent Fuel Treatment for the Modular HTGR," presented at the ANS 1985 Annual Meeting, Boston, MA, June, 1985.

8. Strand, J.B., et. al., "HTGR Fuel Reprocessing Pilot Plant: Results of the Sequential Equipment Operation," GA-A15343, May 1979.

9. Nuclear Waste Policy Act of 1982, Public Law 97-425, January 7, 1983 .

10. Georgia Power, Vogtle Electric Generating Plant Operating License Stage Environmental Report (as amended), March 1985.

11. Code of Federal Regulations, Title 40, Part 60 , Subpart Da, "Standards of Performance for New Stationary Sources," Revised July 22, 1987.

12. Nevada Power Company, et al., Allen-Warner Valley Energy System Environmental Assessment, Vol. 4, "Warner Valley Station," Sept. 1975.

13. "Reactor Siting Criteria," Title 10, U.S. Code of Federal Regulations, Part 100 (10CFR100), Revised January 1, 1985.

14. "Preliminary Safety Information Document for the Standard Modular High-Temperature Gas-Cooled Reactor," DOE-HTGR-86-024, as amended, DOE Document, August 1987.

15. "PRA Procedures Guide," Office Nuclear Regulatory Research, U.S. Nuclear Regulatory Commission, NUREG/CR-2300, January, 1983.

16. "Emergency Planning Bases for the Standard Modular High-Temperature Gas-Cooled Reactor," DOE-HTGR-87-001, Rev. 1, DOE Document, August 1987. 